\title{
Differences in State Anxiety Responses to Combat Pictures between Young Adult Israeli Jews and Israeli Palestinian Arabs
}

\author{
Orrie Dan, Yona Moshe David, Michal Abraham, DoritHadar Souval \\ Department of Psychology, The Max Stern Academic College of Emek Yezreel, Israel \\ Email: orridan@gmail.com
}

Received 30 May 2015; accepted 17 July 2015; published 22 July 2015

Copyright (C) 2015 by authors and Scientific Research Publishing Inc.

This work is licensed under the Creative Commons Attribution International License (CC BY). http://creativecommons.org/licenses/by/4.0/

(c) (i) 0 Den Access

\begin{abstract}
The purpose of the current study was to investigate whether the different political realities of Israeli Jewish citizens and of Israeli Palestinian Arab citizens had differential impacts on the situational anxiety elicited by video clips of military operations. The pictures were taken during the November 2012 Pillar of Defense military operation in Gaza and southern Israel. Participants included 75 (49 female) students at an Israeli college. Of these, 39 were Israeli Jews and 36 were Israeli Arabs. Participants completed the State-Trait Anxiety Inventory (Spiellberger, 1983) and then watched a video clip containing combat pictures. After that they completed the State Anxiety Inventory again. The results showed no differences between Israeli Jewish participants and Israeli Palestinian Arab participants on trait anxiety. Analysis revealed a significant group (Israeli Jews/ Israeli Palestinian Arabs) $X$ condition (before/after watching the video clip pictures) interaction effect. Before watching the video clip, the groups exhibited no difference in state anxiety. After watching the clip, the Israeli Palestinian Arab participants showed greater state anxiety compared with the Israeli Jews.
\end{abstract}

\section{Keywords}

State Anxiety, Minority, Political Realities, Conflict

\section{Introduction}

Researchers describe "unmanageable" conflicts as being total and vast. Such conflicts penetrate the social textures of both sides and impose themselves on individuals as well as on institutions (Rouhana \& Bar-Tal, 1998; Bar-Tal, 2007). They are characterized by a great deal of violence involving vast destruction and by strong feel- 
ings of hostility interwoven into the socialization processes of the contending sides (Bar-Tal, 2007; Ben Meir \& Shaked, 2007). The Israeli-Arab conflict, with the Israeli-Palestinian conflict at its center, is considered an ongoing conflict, similar to the conflicts in Northern Ireland, Sri Lanka, Cyprus, Cambodia and Kashmir (Azar, 1990; Burton, 1990; Kelman, 1999, 2004). Unmanageable conflicts go on for long periods of time, during which prejudice and intense hostility develop between the two sides. The collective memory and the actions of individuals on both sides are affected by events connected to the conflict.

The implications of such conflicts are expressed by low empathy between the sides (Stephan \&Stephan, 1996, 2001), by a clear division into internal and external groups based on the identity of one group (instead of multiple identities) (Brewer, 1986), by a homogeneous perception of the members of the external group (Tajfel \& Turner, 1986; Rouhana, 2008), by attributing negative stereotypes to the members of the external group and by discriminating behaviors favoring the internal group (Abrams \& Hogg, 1990).

\subsection{The Israeli Palestinian Conflict}

The State of Israel was established in 1948 as the national home for the Jewish people. Immediately after Israel declared its independence, war broke out between Israel and its Arab neighbors. At the end of this war, the borders of the State of Israel were determined. Within the borders of this state, an Arab population was included alongside the Jewish population, a population that today is defined as the Arab Palestinian citizens of Israel. In 1967 another war, the Six Day War, took place, in which Israel conquered territories populated by Arabs. These territories are known as Judea, Samaria and the Gaza Strip. Over the years the Palestinian Authority was established within these territories. The Arab population living in the territories of the Palestinian Authority defines itself as Palestinian. A fence, actually a border, separates between the Palestinian Authority and the State of Israel. Since the establishment of the Palestinian Authority in 1994, a ritual of peace negotiations has been going on alongside recurrent violent outbursts of the conflict, such as terror attacks, occupation, bombing and the launching of rockets.

The Arab Palestinian citizens of Israel, who constitute one-fifth of the Israeli population (Central Bureau of Statistics 2006), are closely tied to the Palestinian territories and are often perceived as a hostile minority with national, religious and cultural ties to the enemy - the Arab world. They are often believed to be supportive of subversive activity. Their growing numbers enhance the perception held by many Jewish Israelis that the Arab Israeli population is threatening the very existence of the state of Israel, as well as its Jewish character (Halperin, Canetti-Nisim, \& Hirsch-Hoefler, 2009).

Findings of studies conducted in Israel in recent years among Israeli Jewish and Israeli Arab Palestinian citizens reveal an increasing tendency toward polarization on both sides (Bar-Tal, 2007; Bar-Tal \& Teichman, 2005; Kupermintz, Salomon, \& Hussisi, 2007). The sides disagree on essential issues concerning the character and identity of the state of Israel. The Israeli Jewish population, being the majority, supports Israel as a Jewish-Zionist state that should maintain its Jewish majority. In contrast, the Israeli Palestinian Arab population, being the minority, regards Israel as the shared homeland of the two peoples and expects to be recognized as a national Palestinian minority. Thus, Arabic should have equal status to Hebrew. The majority of the Israeli Palestinian Arab population accepts the existence of the State of Israel, but rejects the idea of a Jewish-Zionist state (Bar-Tal \& Teichman, 2005; Ben Meir \& Shaked, 2007; Rouhana, 2004; Kupermintz, Salomon, \& Hussisi, 2007).

This situation creates completely different realities within the two groups. Most citizens in the Israeli Jewish majority identify with the State of Israel and what it stands for and feel that the state represents them. They accept its institutions and fulfill their obligations as citizens by voting in the elections, serving in the army and the like. In contrast, the Israeli Palestinian Arab citizens of the State of Israel suffer from internal tensions between the conflicting components of their identity: the civic component stemming from their status as Israeli citizens and the national component stemming from their belonging to the Arab population in Israel, to the Arab world and to the Palestinian people (Al-Haj, 1993). As citizens, the Arabs wish to strengthen the process of modernization and gain equality of opportunity like the Jewish population. On the national level, they support the aspirations of their people to achieve independence and to establish a state. Finding the balance between these two components is a difficult and complex task, since the two components, as mentioned above, are involved in an ongoing conflict. As a result of this situation, among other things the Arab population in Israel is rejected both by Israeli Jews and by the Palestinian people. Al-Haj (1993) describes their situation as “double periphery”: liv- 
ing on the fringes of Israeli society as well as on the fringes of Palestinian society.

\subsection{The Effect of Exposure to Violent Events on Minority and Majority Groups}

Research shows that belonging to a minority group increases the probability of developing mental disorders after a catastrophe (Norris et al., 2002). Thus, for example, Brewin, Andrews and Valentine (2000) found that belonging to a minority group within a state becomes a risk factor for developing post-traumatic disorders after major catastrophes. Numerous studies conducted in the USA have illustrated the vulnerability of ethnic minorities, in particular the black and Hispanic populations, to various kinds of trauma. These minority groups are distinguished from the rest of the population by a greater frequency of post-traumatic disorders and bytheir perceptions of the measure of stress stemming from exposure to traumatic events (Perilla, Norris, \& Lavizzo, 2002). Accordingly, when the effects of the events September 11 were measured, a variety of post-traumatic disorders were consistently found within minority groups (Galea et al., 2002).

Similar findings have been reported in studies comparing the Jewish majority and the Palestinian minority in Israel. These studies show greater distress as the result of exposure to ongoing terror among Arab-Palestinian students who are Israeli citizens than among Jewish students. In a study by Somer, Maguen, Or-Chen and Litz (2007), a higher prevalence of PTSD and depression was found among Arab-Palestinian Israeli citizens who live in cities with mixed populations. In addition, Hobfoll, Canetti-Nisim and Johnson (2006) found more posttraumatic syndromes among Arab-Palestinian Israeli citizens than among Jewish citizens. Moreover, a test measuring the level of anxiety among Jews and Arab-Palestinian Israeli citizens at two periods of time found that in the first period, 19 months after a terror attack, Arab-Palestinian Israeli citizens and Jewish citizens suffered from a similar level of post-traumatic disorders. However, in the second period, 44 months after the terror attack, post-traumatic disorders among the Arab-Palestinian Israeli citizens had tripled in intensity, while among Israeli Jews the symptoms had almost completely disappeared.

Based on the findings of these studies, this research seeks to investigate whether the different political realities of the two groups, Israeli Jewish citizens and Israeli Palestinian Arab citizens, have different impacts on the internal psychological experiences of the individuals within these groups in the face of exposure to a violent conflict between the two sides. More specifically, does exposure to violent events connected to the Israeli-Palestinian conflict lead to differential levels of situational anxiety among the Jewish and the Israeli Palestinian Arab populations?

\subsection{Research Background}

The violent events on which this research focuses took place during eight days in November 2012. These events are called Operation Pillar of Defense by the Israelis and the Gaza Warby the Palestinians. Each side has a different perception of these events andof who was responsible, who was the attacker and who was the victim. Yet there is no argument between the sides regarding the fact that the Israeli army launched thousands of attacks on targets in the Gaza Strip, while more than a thousand rockets were fired at Israeli towns and villages. Likewise, there is no argument regarding the fact that the civilian populations on both sides suffered greatly while paying a high price both in property and in human lives.

In the current study we showed Israeli Jewish and Israeli Palestinian Arab participants a short video clip of combat pictures from Operation Pillar of Defense.

The research hypotheses are as follows:

a) No differences between Israeli Jewish participants and Israeli Palestinian Arabs participants are expected on trait anxiety.

b) Before watching the video clip, Israeli Jewish participants and Israeli Arabs participants will exhibit no differences either in trait anxiety or in state anxiety, whereas after watching the video clip there will be differences between Israeli Jewish participants and Israeli Arab participants on state anxiety.

\section{Method}

\subsection{Participants}

Participants included 75 (49 female) first-year undergraduate students at an Israeli college ( $M=23.2 \pm 2.82$ ), of whom 39 participants were Israeli Jews and 36 were Israeli Arabs. The participants received course credit in 
exchange for their participation. All participants gave their informed consent.

\subsection{Instruments}

\subsubsection{Anxiety}

State and trait anxiety were assessed using the State-Trait Anxiety Inventory (Spielberger, 1983), a 40-item scale. Respondents indicated how they "generally" felt by endorsing statements such as "I feel nervous and restless." Endorsements were made on a scale ranging from 1 (almost never) to 4 (almost always). The items were totaled to yield an overall anxiety score, with high scores indicating high state and trait anxiety. In the present sample the internal consistency $\alpha$ scores were 0.86 (pre-test state anxiety), 0.62 (trait anxiety) and 0.88 (post-test state anxiety).

\subsubsection{Combat Pictures Video Clip}

A short video clip was made especially for this experiment. The clip was constructed from still photographs. The contents of the pictures were related to the military conflict in the Pillar of Defense military operation and included such images as flying missiles and fighter airplanes, bombs, damage resulting from bombs, people afraid of bombs, people protesting, newspaper headlines and the like. A total of 50 pictures were used, with 24 pictures presenting the fighting from the perspective of each side, Israeli and Palestinian. Two additional pictures that opened the clip made reference to both sides of the fighting. The first picture showed the name of the military operation and the second showed both the Israeli and the Palestinian flags separated by a flame resulting from a bomb or missile. Each picture was presented for five seconds, with transitional effects between the pictures. A somewhat dramatic sound track accompanied the clip.

\subsection{Procedure}

Participants were randomly invited to a laboratory session in three groups of 25 participants each. The procedure was exactly the same for each group and took place under controlled and identical conditions. The experimenter read the instructions to the participants. First the participants completed the State-Trait Anxiety questionnaire. After that they were shown the combat picture video and instructed to watch it. Finally, after seeing the video they were asked to complete the State-Trait Anxiety questionnaire again.

\section{Results}

Preliminary analyses showed no significant gender difference $(p=0.73,0.39,0.25)$; therefore, all the statistics include all participants.

The first hypothesis suggested that there would no differences between Israeli Jewish participants and Israeli Arab participants on trait anxiety. An independent t-test measure was used. No significant differences was found between Israeli Jewish participants and Israeli Arabs participants on trait anxiety $(t(74)=-0.26, p=0.8)$.

The second hypothesis suggested that before watching the video clip there would be no differences between Israeli Jewish participants and Israeli Arabs participants on state anxiety, whereas after watching the video clip there would be differences between the two groups on state anxiety. A repeated measures ANOVA revealed a significant group (Israeli Jews/Israeli Arabs) X condition (before/after watching the video clip) interaction effect, $F(1,73) 24.08, p<0.001$, effect size $=0.25$. Follow-up contrasts within each group using paired measure t-tests revealed differences between pre- and post-video clip viewing, with the state anxiety of Israeli Jews elevated from $1.63(\mathrm{SD}=0.38)$ to $2.02(\mathrm{SD}=0.53)$, $\mathrm{t}(38)=-4.74, \mathrm{p}<0.001$, and the state anxiety of Israeli Arabs elevated from1.76 $(\mathrm{SD}=0.4)$ to $2.68(\mathrm{SD}=0.35), \mathrm{t}(35)=-13.59, \mathrm{p}<0.001$. Follow-up contrasts between the groups using t-tests revealed differences in state anxiety after watching the video clip, with state anxiety for the Israeli Jews measured at $2.02(\mathrm{SD}=0.53)$ and state anxiety for the Israeli Arabs at $2.67(\mathrm{SD}=0.35), \mathrm{t}(73)=$ $-6.2, \mathrm{p}<0.001$ (Figure 1).

\section{Discussion}

In recent years, research interest has grown regarding the emotions felt by individuals as a result of their membership in or identification with a certain group or society (Mackie, Devos, \& Smith, 2000; Smith \& Mackie, 2008). 


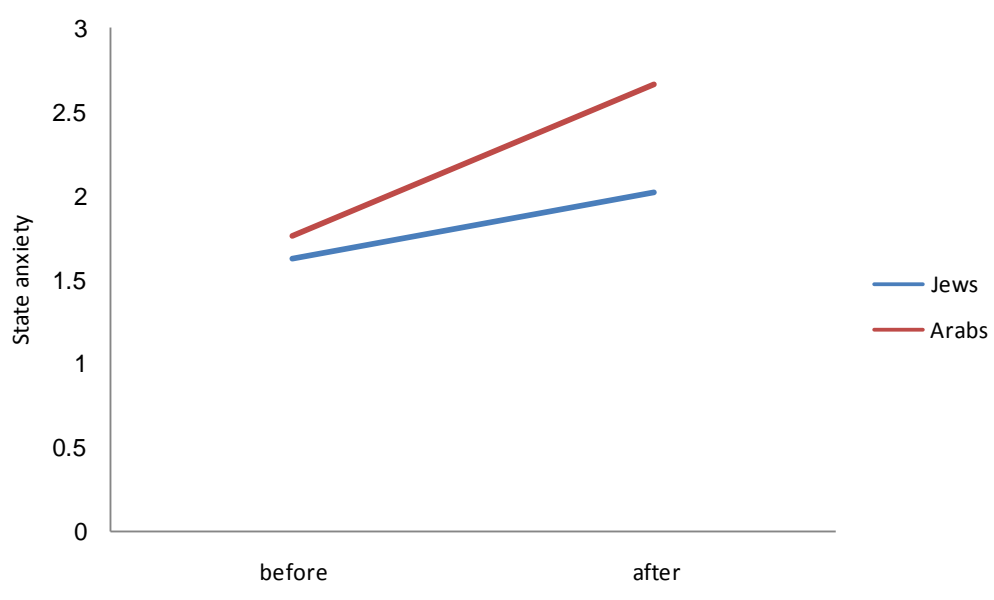

Figure 1. Differences between Israeli Jews and Israeli Palestinian Arabs in state anxiety response means, before, and after watching video clip of military operations.

The aim of the present study was to examine the relationships between the political realities of Israeli Jewish and Israeli Palestinian Arab citizens and situational anxiety, elicited by showing video clip pictures of a military operation.

The first hypothesis was that on an ordinary day at a college, no differences in trait anxiety were expected between Israeli Jewish participants and Israeli Palestinian Arabs participants. This hypothesis was clearly confirmed. The results indicate that Israeli Jewish and Israeli Palestinian Arab citizens do not differ in their trait anxiety. This result is in line with previous studies showing no differences in anxieties between Israeli Jewish and Israeli Palestinian Arab citizens (Zeidner, 1989).

The second hypothesis was that prior to watching the video clip there would be no differences between Israeli Jewish participants and Israeli Arabs participants on state anxiety, whereas after watching the video clip there would be differences between Israeli Jewish participants and Israeli Arabs participants on state anxiety. This hypothesis was confirmed. Results show that at the beginning of the session, before watching the video clip, there was no difference in state anxiety between Israeli Jewish and Israeli Palestinian Arab citizens, but after watching a video clip showing military operation pictures, the state anxiety of all participants was significantly elevated. This result can be explained by previous findings showing that emotions become more extreme under stressful conditions (Huddy, Feldman, \& Cassese, 2009; Skitka, Bauman, \& Mullen, 2004) and that individuals may experience emotions in response to events that affect other members of a group with which they identify (Halperin, Sharvit, \& Gross, 2011; Mackie et al., 2000; Wohl, Branscombe, \& Klar, 2006; Dumont, Yzerbyt, Wigboldus, \& Gordin, 2003). Moreover, the elevated state anxiety was more pronounced among the Israeli Palestinian Arab participants compared with the Israeli Jewish participants. Results indicated differences in state anxiety between Israeli Jews and Israeli Palestinian Arabs after watching the video clip of the military operation pictures, such that the Israeli Palestinian Arab citizens exhibited greater state anxiety than the Israeli Jewish citizens. This result can be explained by the differing political realities of the Jewish and Arab Palestinian Israeli citizens.

Watching the military operation pictures increased state anxiety among both groups, Jews and Arabs. However, the state anxiety among the Arab participants was not merely a result of the fear of getting hurt in a war. It also represented the triggering of two components of their identity conflict: the citizen component (Israeli identity) and national identity (Palestinian identity). For Arab participants the reality shown in the clip is complex. Those who shoot rockets and endanger me (Palestinians in Gaza) are part of my people, and I am part of them. Those who fight against my people (Israelis) are also part of my people, and I am part of them. The clip showed the suffering of both sides. Jewish participants recognized a clear picture of good and bad in the clip and received moral affirmation for their country's actions. The Arab participants felt fear for their lives on both the physical and the psychological levels (Where do I belong?) (Hagerty \& Williams, 1999; Sargent, Williams, Hagerty, Lynch-Sauer, \& Hoyle, 2002). These results coincide with previous research knowledge emphasizing that belonging to a minority group is one of the risk factors for mental illness after experiencing a traumatic event 
(Loo, Fairbank, \& Chemtob, 2005; Norris et al., 2002; Palinkas, Petterson, Russel, \& Downs, 1993).

Moreover, social psychology research has demonstrated that threatened individuals and groups usually cope with threat by developing hostile attitudes toward out-groups, attempting to reduce their relative power and supporting actions that potentially harm out-group members in various ways (Maddux, Galinsky, Cuddy, \& Polifroni, 2008; Rios-Morrison \& Ybarra 2008; Pettigrew, 2003). This process may be exacerbated when these minority groups are believed to be associated with the enemy (Bar-Tal \& Labin, 2001; Pettigrew, 2003; Skitka, Bauman, \& Mullen 2004). Following decades of Israeli-Arab conflict, Israeli Palestinian Arab citizens are a major target of politicalintolerance (Halperin, Canetti-Nisim, \& Hirsch-Hoefler, 2009; Shamir \& Sagiv-Schifter, 2006; Shamir \& Sullivan, 1985). They are perceived by Israeli Jews to be a hostile minority with intimate connections with the enemies of Israel. At times when public safety is threatened, rage is frequently aimed at that minority group and their members. Watching the combat pictures reminds the Israeli Arab citizen show the majority perceives them as being part of the enemy and may be hostile toward them. Therefore their state anxiety rises.

Although interesting, the present study has some limitations. First, it depended on participants' self-reports of their state and trait anxiety. Some participants may have been unable to give accurate reports of their feelings in the described situations or may have been embarrassed about sharing their true feelings. Future studies should incorporate physical assessment of anxiety along with subjective reporting on questionnaires. Second, the minority group was treated as a homogeneous group, whereas it comprises Muslim and Christian Israeli Palestinian Arab citizens.

Although defined as Palestinians, these two groups have different historical narratives that influence their political reality in Israel (their identification with the state, feelings of belonging and the like). It is reasonable to assume that this political reality influences their interpretation of the conflict differently, as well as their level of state anxiety. Finally, because this study examined only anxiety, future laboratory studies with proper controls are needed to test the effects of more discrete emotions, including hate and anger.

The current study demonstrated how watching a video clip of combat pictures caused state anxiety to increase among all young adult participants. Moreover, this rise in state anxiety was more pronounced within the minority group that is known to be associated with the enemy. These findings contribute to a growing body of literature demonstrating that during times of threat, minority groups may suffer from extreme situation anxiety. Regardless of the direction of future research, it is our hope that in times of threats like this the government will remember that it is responsible for the well-being of all its citizens, including its minorities, especially those that are more vulnerable and perceived by the majority as identifying with the enemy. These preliminary findings should be further validated in the future, using a complementary experimental design.

\section{References}

Abrams, D., \& Hogg, M. A. (1990). Social Identification, Self Categorization and Social Influence. European Review of Social Psychology, 1, 195-228. http://dx.doi.org/10.1080/14792779108401862

Al-Haj, M. (1993) The Impact of the Intifada on the Arabs in Israel: The Case of A Double Periphery. In A. Cohen, \& G. Wolfsfeld (Eds.), Framing the Intifada, Media and People (pp. 64-75). Norwood, NJ: Ablex.

Azar, E. E. (1990). The Management of Protracted Social Conflict. Hampshire, UK: Dartmouth Publishing.

Bar-Tal, D. (2007). Social-Psychological Foundations of Intractable Conflict. American behavioral Scientist, 50, $1430-1453$. http://dx.doi.org/10.1177/0002764207302462

Bar-Tal, D., \& Labin, D. (2001). The Effect of a Major Event on Stereotyping: Terrorist Attacks in Israel and Israeli Adolescents' Perceptions of Palestinians, Jordanians and Arabs. European Journal of Social Psychology, 31, 265-280. http://dx.doi.org/10.1002/ejsp.43

Bar-Tal, D., \& Teichman Y. (2005). Stereotypes and Prejudice in Conflict: Representations of Arabs in Israeli Jewish Society. Cambridge, UK and New York: Cambridge University Press. http://dx.doi.org/10.1017/CBO9780511499814

Ben Meir, Y., \& Shaked, D. (2007) The People Speak: Israeli Public Opinion on National Security 2005-2007. Memorandum, Vol. 90. Tel Aviv: Institute for National Security Studies.

Brewer, M. B. (1986) The Role of Ethnocentrism in Intergroup Conflict. In S. Worchel, \& W. G. Austin (Eds.), Psychology of Intergroup Relations (pp. 88-102). Chicago: Nelson-Hall.

Brewin, C. R., Andrews, B., \& Valentine, J. D. (2000). Meta-Analysis of Risk Factors for Posttraumatic Stress Disorder in Trauma-Exposed Adults. Journal of Consulting and Clinical Psychology, 68, 748-766. 
http://dx.doi.org/10.1037/0022-006X.68.5.748

Burton, J. (1990) Conflict: Human Needs Theory. New York: St. Martins Press.

Dumont, M., Yzerbyt, V., Wigboldus, D., \& Gordijn, E. H. (2003). Social Categorization and Fear Reactions to the September 11th Terrorist Attacks. Personality and Social Psychology Bulletin, 29, 1509-1520. http://dx.doi.org/10.1177/0146167203256923

Galea, S., Ahern, J., Resnick, H., Kilpatrick, D., Bucuvalas, M., Gold, J., \& Vlahov, D. (2002). Psychological Sequelae of the September 11 Terrorist Attacks in New York City. The New England Journal of Medicine, 346, 982-987.

http://dx.doi.org/10.1056/NEJMsa013404

Hagerty, B. M., \& Williams, R. A. (1999). The Effects of Sense of Belonging, Social Support, Conflict and Loneliness on Depression. Nursing Research, 48, 215-219. http://dx.doi.org/10.1097/00006199-199907000-00004

Halperin, E., Canetti-Nisim, D., \& Hirsch-Hoefler, S. (2009). The Central Role of Group-Based Hatred as an Emotional Antecedent of Political Intolerance: Evidence from Israel. Political Psychology, 30, 93-123. http://dx.doi.org/10.1111/j.1467-9221.2008.00682.x

Halperin, E., Sharvit, K., \& Gross, J. J. (2011). Emotion and Emotion Regulation in Intergroup Conflict: An Appraisal-Based Framework. In D. Bar-Tal (Ed.), Intergroup Conflicts and Their Resolution: A Social Psychological Perspective (pp. 83103). New York: Psychology Press.

Hobfoll, S. E., Canetti-Nisim, D., \& Johnson, R. J. (2006). Exposure to Terrorism, Stress-Related Mental Health Symptoms, and Defensive Coping among Jews and Arabs in Israel. Journal of Consulting and Clinical Psychology, 74, 207-218. http://dx.doi.org/10.1037/0022-006X.74.2.207

Huddy, L., Feldman, S., \& Cassese, E. (2009). Terrorism, Anxiety, and War. In W. G. K. Stritzke, S. Lewandowsky, D. Denemark, J. Clare, \& F. Morgan (Eds.), Terrorism and Torture: An Interdisciplinary Perspective (pp. 290-312). New York: Cambridge University Press. http://dx.doi.org/10.1017/CBO9780511581199

Kelman, H. (1999). The Interdependence of Israeli and Palestinian National Identities: The Role of the Other in Existential Conflicts. Journal of Social Issues, 55, 581-600. http://dx.doi.org/10.1111/0022-4537.00134

Kelman, H. (2004). Reconciliation as Identity Change: A Social-Psychological Perspective. In Y. Bar-Simon-Tov (Ed.), From Conflict Resolution to Reconciliation (pp. 111-124). Oxford: Oxford University Press. http://dx.doi.org/10.1093/acprof:oso/9780195166439.003.0006

Kupermintz, H., Salomon, G., \& Hussisi, R. (2007). Mutual Perceptions of Jewish and Arab Youth in Israel: $2004-2005$. Haif: Center for Research on Peace Education, Haifa University.

Loo, C. M., Fairbank, J. A., \& Chemtob, C. M. (2005). Adverse Race-Related Events as a Risk Factor for Posttraumatic Stress Disorder in Asian American Vietnam Veterans. The Journal of Nervous and Mental Disease, 193, 455-463. http://dx.doi.org/10.1097/01.nmd.0000168239.51714.e6

Mackie, D. M., Devos, T., \& Smith, E. R. (2000). Intergroup Emotions: Explaining Offensive Action Tendencies in an Intergroup Context. Journal of Personality and Social Psychology, 79, 602-616. http://dx.doi.org/10.1037/0022-3514.79.4.602

Maddux, W. W., Galinsky, A. D., Cuddy, A. J. C., \& Polifroni, M. (2008). When Being a Model Minority Is Good and Bad: Realistic Threat Explains Negativity toward Asian Americans. Personality and Social Psychology Bulletin, 34, 74-89. http://dx.doi.org/10.1177/0146167207309195

Norris, F., Friedman, M., Watson, P., Byrne, C., Diaz, E., \& Kaniasty, K. (2002). 60, 000 Disaster Victims Speak. Part I: An Empirical Review of the Empirical Literature, 1981-2001. Psychiatry, 65, 207-239. http://dx.doi.org/10.1521/psyc.65.3.207.20173

Palinkas, L. A., Petterson, J. S., Russell, J., \& Downs, M. A. (1993). Community Patterns of Psychiatric Disorders after the Exxon Valdez Oil Spill. American Journal of Psychiatry, 150, 1517-1523. http://dx.doi.org/10.1176/ajp.150.10.1517

Pettigrew, T. F. (2003). Peoples under Threat: Americans, Arabs, and Israelis. Peace and Conflict: Journal of Peace Psychology, 9, 69-90. http://dx.doi.org/10.1207/S15327949PAC0901 03

Perilla, J. L., Norris, F. H., \& Lavizzo, E. A. (2002). Ethnicity, Culture, and Disaster Response: Identifying and Explaining Ethnic Differences in PTSD Six Months after Hurricane Andrew. Journal of Social and Clinical Psychology, 21, 20-45. http://dx.doi.org/10.1521/jscp.21.1.20.22404

Rios-Morrison, K., \& Ybarra, O. (2008). The Effects of Realistic Threats and Group Identification on Social Dominance Orientation. Journal of Experimental Social Psychology, 44, 156-163. http://dx.doi.org/10.1016/j.jesp.2006.12.006

Rouhana, N. N. (2004). Group Identity and Power Asymmetry in Reconciliation Processes: The Israeli-Palestinian Case. Peace and Conflict: Journal of Peace Psychology, 10, 33-52. http://dx.doi.org/10.1207/s15327949pac1001 3 
Rouhana, N. N. (2008). Reconciling History and Equal Citizenship in Israel: Democracy and the Politics of Historical Denial. In W. Kymlicka, \& B. Bashir (Eds.), The Politics of Reconciliation in Multicultural Societies (pp. 70-93). Oxford: Oxford University Press.

Rouhana, N. N., \& Bar-Tal, D. (1998). Psychological Dynamics of Intractable Ethnonational Conflicts: The Israeli-Palestinian Case. American Psychologist, 53, 761-770. http://dx.doi.org/10.1037/0003-066X.53.7.761

Sargent, J., Williams, R. A., Hagerty, B., Lynch-Sauer, J., \& Hoyle, K. (2002). Sense of Belonging as a Buffer against Depressive Symptoms. Journal of the American Psychiatric Nurses Association, 8, 120-129. http://dx.doi.org/10.1067/mpn.2002.127290

Shamir, M., \& Sagiv-Schifter, T. (2006). Conflict, Identity, and Tolerance: Israel in the Al-Aqsa Intifada. Political Psychology, 27, 569-596. http://dx.doi.org/10.1111/j.1467-9221.2006.00523.x

Shamir, M., \& Sullivan, J. (1985). Jews and Arabs in Israel: Everybody Hates Somebody Sometimes. Journal of Conflict Resolution, 29, 283-305. http://dx.doi.org/10.1177/0022002785029002006

Skitka, L. J., Bauman, C. W., \& Mullen, E. (2004). Political Tolerance and Coming to Psychological Closure following September 11, 2001: An Integrative Approach. Personality and Social Psychology Bulletin, 30, 743-756. http://dx.doi.org/10.1177/0146167204263968

Smith, E. R., \& Mackie, D. M. (2008). Intergroup Emotions. In M. Lewis, J. M. Haviland-Jones, \& L. F. Barrett (Eds.), Handbook of Emotions (3rd ed., pp. 428-439). New York: NY Guilford Press.

Somer, E., Maguen, S., Or-Chen, K., \& Litz, B. T. (2007). Managing Terror: Differences between Jews and Arabs in Israel. International Journal of Psychology, 44, 138-146. http://dx.doi.org/10.1080/00207590701609076

Spielberger, C. D. (1983). State-Trait Anxiety Inventory: A Comprehensive Bibliography. Palo Alto, CA: Consulting Psychologists Press.

Stephan, W.G., \& Stephan, C.W. (1996). Intergroup Relations. Boulder, CO: Westview Press.

Stephan, W.G., \& Stephan, C.E. (2001). Improving Intergroup Relations. Thousand Oaks, CA: Sage Publication.

Tajfel, H., \& Turner, J. (1986). An Integrative Theory of Intergroup Conflict. In W. G. Austin, \& S. Worchel (Eds.), Psychology of Intergroup Relations (pp. 7-24). Monterey, CA: Brooks Cole.

Wohl, M. J. K., Branscombe, N. R., \& Klar, Y. (2006). Collective Guilt: Justice-Based Emotional Reactions When One’s Group Has Done Wrong or Been Wronged. European Review of Social Psychology, 17, 1-37. http://dx.doi.org/10.1080/10463280600574815

Zeidner, M. (1989). Social Anxiety among Jewish and Arab Students in Israel. Journal of Social Psychology, 129, 415-418. http://dx.doi.org/10.1080/00224545.1989.9712058 